\title{
Az ösztrogénmetabolizmus várandósság alatt
}

\author{
Kovács Krisztián ${ }^{1}$. Vásárhelyi Barna dr. ${ }^{1}$ \\ Gyarmati Béla dr. ${ }^{2}$ - Karvaly Gellért dr. ${ }^{1}$ \\ ${ }^{1}$ Semmelweis Egyetem, Általános Orvostudományi Kar, Laboratóriumi Medicina Intézet, Budapest \\ ${ }^{2}$ Uzsoki utcai Kórház, Szülészet-Nőgyógyászati Osztály, Budapest
}

\begin{abstract}
Az ösztrogénhormonok metabolizmusa során oxidált formák, szerkezeti izomerek és konjugált termékek jelennek meg számos szövetben lokálisan, emellett a szisztémás keringésben. A metabolizmus megváltozása feltételezhetően számos kórfolyamattal összefügg. A célzott ösztrogénmetabolomikai kutatásokra idáig jórészt postmenopausalis, illetve malignitásokkal és adverz immunrendszeri folyamatokkal összefüggésben került sor. Noha az ösztriol gestatiót fenntartó szerepe és az ösztrogénmetabolitok biológiai aktivitása ismert, viszonylag kis számú közleményben foglalkoztak e vegyületek várandósság alatti keletkezésével és átalakulásaival. Áttekintő közleményünkben bemutatjuk az ösztrogénmetabolitok terhesség alatt történő képződését, illetve összefoglaljuk az ismereteket a gestatiós komplikációkban azonosított szerepükre vonatkozóan.
\end{abstract}

Orv Hetil. 2019; 160(26): 1007-1014.

Kulcsszavak: várandósság, placenta, ösztrogénmetabolizmus, praeeclampsia, ösztriol

\section{Estrogen metabolism during pregnancy}

The extensive metabolism of estrogen hormones, where oxidized forms, structural isomers and conjugated products appear in many tissues locally as well as in systemic circulation, is believed to be associated with a number of diseases. Targeted estrogen metabolomic studies have been largely associated with postmenopausal, malignant advert immune conditions. Although the role of estriol in maintaining pregnancy and the biological activity of estrogen metabolites is known, a relatively small number of publications have addressed the formation and transformation of these compounds during pregnancy. The aim of this study is to present in detail the formation and progression of estrogen metabolites during pregnancy and to summarize the knowledge of their role in undesirable processes occurring during gestation.

Keywords: pregnancy, placenta, estrogen metabolism, preeclampsia, estriol

Kovács K, Vásárhelyi B, Gyarmati B, Karvaly G. [Estrogen metabolism during pregnancy]. Orv Hetil. 2019; 160(26): 1007-1014.

(Beérkezett: 2019. február 1.; elfogadva: 2019. február 24.)

\begin{abstract}
Rövidítések
$2 \mathrm{MeOE} 2=(2$-methoxyestradiol $)$ 2-metoxi-ösztradiol; $2 \mathrm{OHEl}=(2$-hydroxyestrone $) 2$-hidroxi-ösztron; 2OHE2 = (2-hydroxyestradiol) 2-hidroxi-ösztradiol; 4OHEl = 4-hidroxi-ösztron; 4OHE2 = (4-hydroxyestradiol) 4-hidroxi-ösztradiol; 16 $\alpha \mathrm{OH}$-DHEAS = 16-alfa-hidroxi-DHEAS; 16 $\alpha \mathrm{OHEl}$ $=(16-\alpha$ hydroxiestrone $)$ 16-alfa-hidroxi-ösztron; 17 $\beta$ HSDl $=$ $17 \beta$-hidroxi-szteroid-dehidrogenáz-1; AMP $=($ adenosine monophosphate) adenozin-monofoszfát; $\mathrm{cAMP} / \mathrm{PKA}=$ (cyclic adenosine monophosphate/protein kinase A) ciklikus adenozin-monofoszfát $/$ proteinkináz-A; COMT $=$ (catechol- $\mathrm{O}$ -
\end{abstract}

methyltransferase) katechol-O-metiltranszferáz; CYP = citokróm P450; DHEA = (dehydroepiandrosterone $)$ dehidroepiandroszteron; DHEAS $=$ (dehydroepiandrosterone-sulphate $)$ dehidroepiandroszteron-szulfát; E1 = (estrone $)$ ösztron; E2 = (estradiol) ösztradiol; E3 = (estriol) ösztriol; E4 = (estetrol $)$ ösztetrol; ER = (estrogen receptor) ösztrogénreceptor; GSH = glutation; GST $=$ (glutathione $S$-transferase) glutation-Stranszferáz; LC = (liquid chromatography) folyadékkromatográfia; $\mathrm{LDL}=($ low-density lipoprotein $)$ alacsony sürúségú lipoprotein; $\mathrm{mRNS}=$ (messenger RNA) hírvivő RNS; MS = (mass spectrometry) tömegspektrometria; $\mathrm{NQOl}=(\mathrm{NAD}(\mathrm{P})$ 
$\mathrm{H}$ : quinone oxidoreductase) $\mathrm{NAD}(\mathrm{P}) \mathrm{H}$-kinon-oxidoreduktáz; $\mathrm{PE}=$ praeeclampsia $; \mathrm{RNS}=$ ribonukleinsav; $\mathrm{SERM}=$ (selective estrogen receptor modulator) szelektív ösztrogénreceptor-modulátor; STS = (steroid sulfatase $)$ szteroid szulfatáz; SULT = (sulfotransferase) szulfotranszferáz; UDP-UGT $=$ (uridine diphosphate-glucuronosyltransferase) uridin-difoszfát-glukuronozil-transzferáz

Az ösztrogéneket az orvostudomány nagyjából 100 éve ismeri. Szarvasmarhák ovariumának porításával készült tabletta - Ovariin néven - már a XIX. század végén létezett a menopausával járó nehézségek kezelésére. A három legismertebb természetes ösztrogénvegyület: az ösztron (E1), majd az ösztradiol (E2), végül az ösztriol (E3) izolálására, elnevezésére és szerkezetazonosítására az 1920-30-as években került sor [1]. Az ösztrogénhormonok és a terhesség kapcsolatát feltáró kísérleteket amelyek többek között a fetomaternoplacentaris egység létezésének igazolásához vezettek - a múlt század 195060-as éveiben végezték. Ebben az időszakban számos ösztrogénmetabolit, illetve metabolikus útvonal is azonosításra került [2]. Említésre méltó Diczfalusy Egon, aki a téma korai úttörőjeként számos eredménnyel - például az ösztrogének 15 $\alpha$-hidroxilációs metabolikus útvonalának feltérképezésével terhességben - járult hozzá az ismeretek bővüléséhez [3]. A 2000-es évek első évtizedében a folyadékkromatográffal kapcsolt tandem tömegspektrometria (LC-MS/MS) elterjedése lehetővé tette a nagy érzékenységű ( $100 \mathrm{pg} / \mathrm{ml}$ alatti) meghatározásokat és az ösztrogénvegyületek egymás melletti analízisét, ami lendületet adott immár az ösztron, az ösztradiol és a fontosabb metabolitok - a 2-es, 4-es és 16-os útvonal termékeinek - együttes vizsgálatára [4].
A közelmúlt klinikai irodalma az ösztrogénmetabolom eltéréseinek jellegzetességeit elsősorban a postmenopausával, illetve a daganatos és autoimmun betegségekkel összefüggésben vizsgálta. Ezekre vonatkozóan nőgyógyászati tumorokban: emlő- és ovariumcarcinomában $[5,6]$, autoimmun folyamatokban $[7,8]$, továbbá a tüdő [9] és a prostata $[10,11]$ malignus megbetegedéseiben vannak ismeretek.

Mivel az ösztrogének metabolizmusa várandósságban alapvető sajátosságokat mutat, és a terhességet érintő számos kórképben diagnosztikai, prognosztikai értékkel rendelkezhetnek, az alábbiakban áttekintjük a területre vonatkozó ismereteket.

\section{Ösztrogénprekurzorok szintézise a fetomaternoplacentaris egységben}

Várandósság során az endogén ösztrogének termelésében jelentős növekedés tapasztalható. Szintézisük döntő részben a placentában zajlik, amely a valódi élettani kapcsolatot teremti meg az anya és a magzat között. A placentában a mellékvesekéreghez képest az anyai szervezet előanyagaiból a rendkívül intenzív szteroidhormon-szintézis kezdeti és végső lépései játszódnak le. A placentában a szintézis az androgének pregnánvázas előanyagokból történő termeléséhez elengedhetetlen CYP17Al enzim hiánya miatt csak a progeszteron képződéséig tart; az anyai vérben lévő LDL-koleszterin kiindulási anyaga a pregnenolonnak is, mely átjut a magzati keringésbe; a bioszintézis a magzati mellékvesében és májban folytatódik (1. ábra). A CYP17Al, a gestatio egyik legjelentôsebb, bifunkcionális enzime 17 $\alpha$-hidroxiláz- és 17,20-liáz-aktivitással rendelkezik,

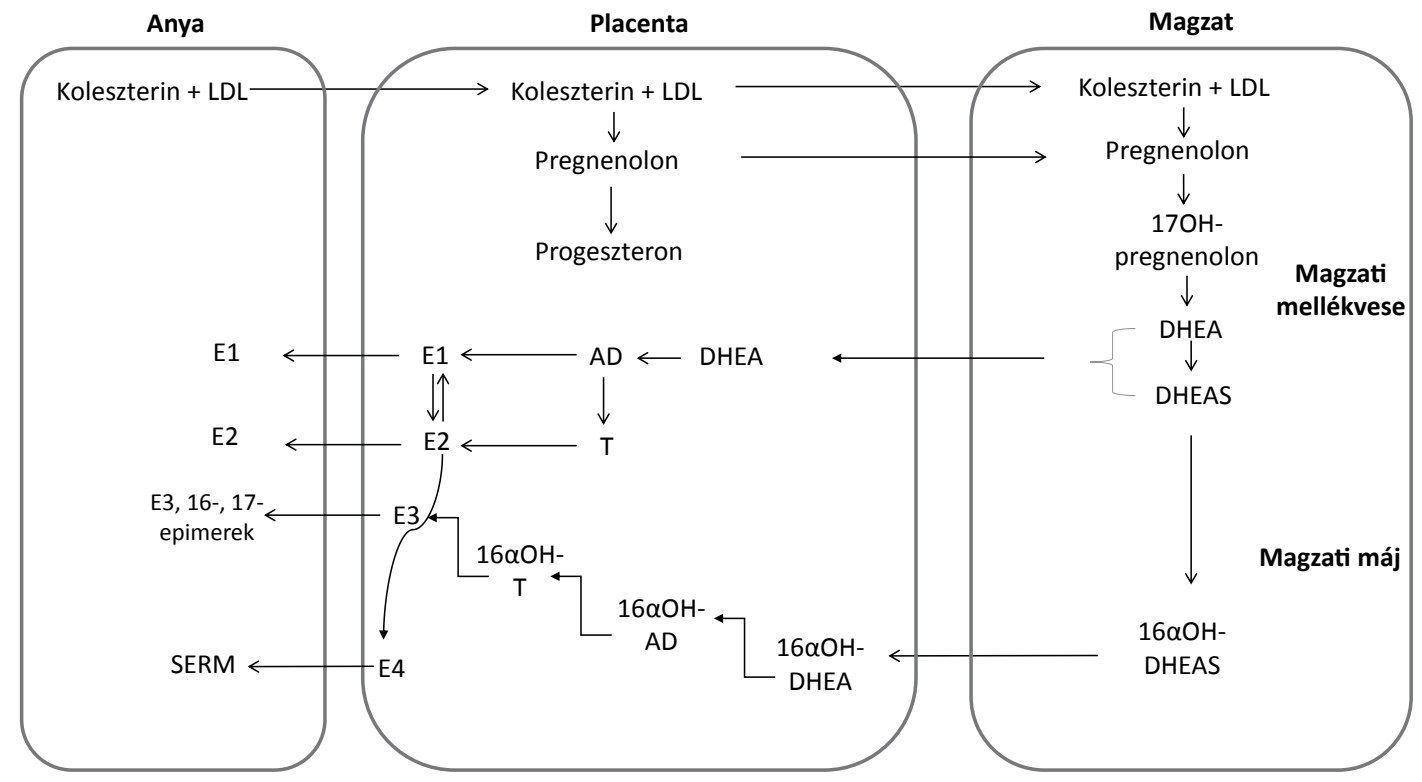

1. ábra

A gesztációs ösztrogénszintézis folyamata

$16 \alpha \mathrm{OH}$-AD = 16-alfa-hidroxi-androszténdion; $16 \alpha \mathrm{OH}-\mathrm{T}=; 16 \alpha$-hidroxi-tesztoszteron; $\mathrm{AD}=$ androszténdion; DHEA = dehidroepiandroszteron; DHEAS = dehidroepiandroszteron-szulfát; $\mathrm{LDL}=$ alacsony sűrűségű lipoprotein; SERM = szelektív ösztrogénreceptor-modulátor 


\begin{tabular}{|c|c|}
\hline Lokalizáció & Enzimek \\
\hline Syncytiotrophoblast & $\begin{array}{l}\text { Aromatáz (CYP19A1), } \\
\text { HSD17ß1, HSD3ß1, } \\
\text { Szulfatázok (SULTs) }\end{array}$ \\
\hline Cytotrophoblast & HSD17ß1, COMT \\
\hline Magzati érendothelsejtek & HSD $17 \beta 2$ \\
\hline Anyai érendothelsejtek myocytái & COMT \\
\hline Anyai erek myocytái & Aromatáz (CYP19Al) \\
\hline $\begin{array}{l}\text { Anyai és magzati mellékvese és } \\
\text { máj }\end{array}$ & SULT2Al, SULT1El \\
\hline Decidualis sejtek & COMT \\
\hline
\end{tabular}

COMT $=$ katechol-O-metiltranszferáz; HSD = hidroxi-szteroid-dehidrogenáz; SULT $=$ szulfotranszferáz

mely a pregnenolont $17 \alpha$-hidroxi-pregnenolonná és DHEA-vá alakítja. Számos tanulmány igazolta a placentaris CYP17Al mRNS-expresszióját, a szintézisben részt vevő többi enzimhez (3ßHSDl, CYP19Al, CYPl1Al és 17ßHSD3) képest alacsony mértékben. A CYP17Al általi $17 \alpha \mathrm{OHP}$-szintézis a trophoblastban zajlik, mely a cAMP/PKA (ciklikus adenozin-monofoszfát/proteinkináz-A) útvonalon szabályozódik (1. táblázat) [12].

A DHEA átalakítása DHEAS-szá ACTH-stimulus hatására a SULT-ban gazdag magzati mellékvesék fetalis zónájában zajlik le, míg a 16 $\mathrm{OH}$-DHEAS a magzati májban szintetizálódik. A DHEAS hidroxilációját a CYP3A7 enzim végzi. A fetalis máj CYP3A7 enzimet a terhesség 50-60. napja között kezd el expresszálni. A magzatból nagy mennyiségű DHEAS és $16 \alpha \mathrm{OH}-\mathrm{DHEAS}$ kerül vissza a placentába, és az átalakítási lépések ettől a pont- tól ott folytatódnak. A placentaris ösztrogének gátolják a 17ßHSDl enzim aktivitását a magzati mellékvesékben, ezzel tovább fokozva azok DHEAS-termelését. A DHEA felszabadulása a szulfátkonjugátumból a syncytiotrophoblastban történik. A placentában a DHEA-ból androszténdion, valamint tesztoszteron keletkezik.

\section{Ösztrogénszintézis}

Az ösztrogénvegyületek a bioszintézis végtermékei; ahhoz, hogy az „A”-gyưrú aromatizációja és a Cl0 szénatomhoz kapcsolódó metilcsoport távozása megtörténjen, aromatáz enzim (CYP19Al) jelenléte szükséges. Az aromatizáció során az androszténdion El-gyé, a tesztoszteron E2-vé alakul. A terhesség második trimeszterétől a várandós nők keringésében legnagyobb koncentrációban 16 $\alpha$-hidroxilált ösztrogének mérhetők. Közülük a legismertebb E3 (16 $\alpha$-hidroxi-17 $\beta$-ösztradiol) bioszintézise ugyanakkor a várandósság alatt az E1 és az E2 keletkezésétől független. Ennek az az oka, hogy a placentában nem termelődik 16 $\alpha$-hidroxiláz enzim, az E3 prekurzorai tehát elsősorban magzati eredetű 16 $\alpha$-hidroxiandrogének. Milewich és mtsai a 16 $\alpha$-hidroxiláz-aktivitást első és második trimeszterbeli humán abortuszok magzati és placentaszöveteiből előállított mikroszómákban mérték. 16 $\alpha$-hidroxiláz-aktivitást 14 vizsgált magzati szövet közül 13-ban, így többek között a májban, a mellékvesében, a tüdőben, a vesékben, a szívben, az agy bizonyos területein, a bőrben és a gyomor-bél traktusban sikerült kimutatni, ugyanakkor elhanyagolható aktivitást mértek a placenta szövetében. A mikroszomális enzim legmagasabb fajlagos aktivitását a magzati májban és a magzat mellékvesekérgében találták [13]. Mind a máj, mind a mellékvesekéreg 16 $\alpha$-hidroxilációs aktivitása

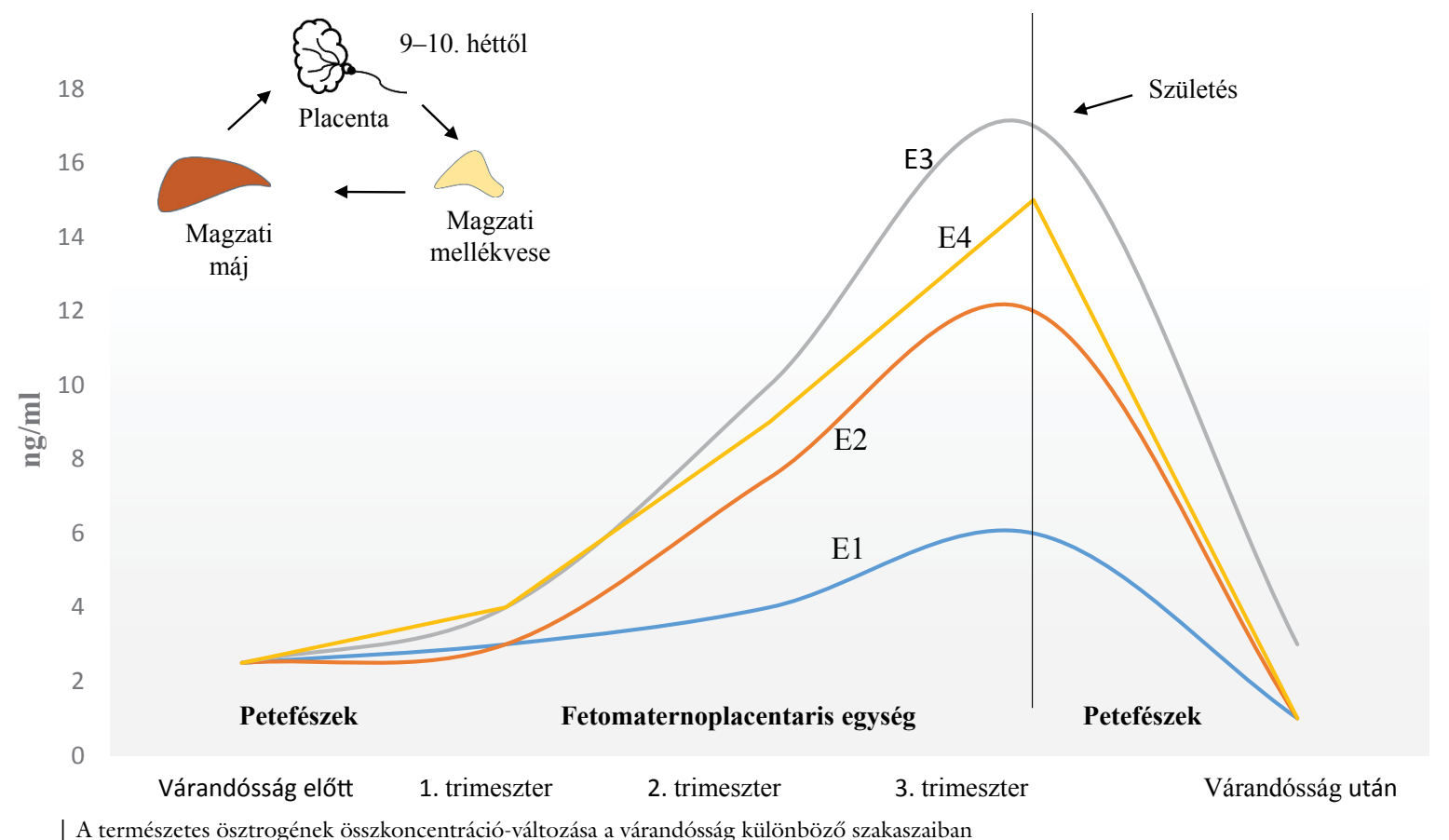


postnatalisan eltünik. Hickey és mtsai ikerterhességek vizsgálata során azt találták, hogy a köldökzsinórvér ösztrogénkoncentrációja következetesen alacsonyabb volt az ikerszülések során, függetlenül a magzatok nemétől és gestatiós korától. Ellentétes nemű ikrek köldökzsinórvérének E3- és E4 (ösztetrol)-szintjei között szoros korrelációt állapítottak meg. Mindez arra utal, hogy a magzati mellékvese-placenta tengely a magzat ösztrogénszintjét nemtől független módon határozza meg [14].

Az E3 emelkedett szintjei az anyai keringésben a gestatio 9. hetétől mutathatók ki, ez az időbeli kapcsolat megegyezik a szteroidogén érés korai stádiumával a magzati mellékvesekéregben. A mérhető koncentráció kb. $0,05 \mathrm{ng} / \mathrm{ml} 9$ héten keresztül, majd egyre magasabb, akár $100 \mathrm{ng} / \mathrm{ml}$ fölé is emelkedhet [15]. Terhességen kívül az ösztriolszint jellemzően nem haladja meg a 0,01 $\mathrm{ng} / \mathrm{ml}-\mathrm{t}$ (2. ábra).

Várandósság során kimutatható mennyiségben termelődő hormon az E4. Az E4 az E3-on keresztül az E2 $15 \alpha / 16 \alpha$ hidroxilációjának terméke, mely reakció a magzati májban következik be. Az E4 koncentrációja szignifikánsan magasabb a magzati vérkeringésben, mint az anyáéban. A $15 \alpha$-hidroxiláz enzim specifikus a magzati májra, születés után képződése gátlódik, ezért az E4 sem termelődik tovább születés után. Az E4 pontos szerepe jelenleg kevésbé tisztázott, valószínúleg szelektív ösztrogénreceptor-modulátorként (SERM) múködik [16].

\section{Ösztrogénmetabolitok keletkezése várandósság során}

A fetomaternoplacentaris egység által termelt ösztrogének metabolizmusának sajátossága, hogy az átalakulások számos helyen - a placenta mellett elsősorban a magzati és az anyai májban - mennek végbe. A keletkező hormonok és metabolitjaik részben recirkulálnak a magzati májba, ami a folyamatok összetettségét tovább növeli. A metabolitok keletkezése ezért nem teljes mértékben tisztázott.

Az átalakulási termékek szerkezetüket tekintve nagymértékű egyezést mutatnak a terhességen kívül keletkező metabolitokéval, ugyanakkor a domináns lebontási útvonalak eltérőek (3. ábra). A fázis I. átalakítás során az E1-ből és E2-ből keletkező fó metabolitok a 2OHE2 és a 2OHEl, amelyek mellett sokkal kisebb mértékben a 4-es pozícióban hidroxilált termékek is képződnek. Az E3 a legnagyobb mértékben $16 \alpha \mathrm{OHEl-ná} \mathrm{és} \mathrm{16ketoE2-}$ vé alakul át. Az utóbbi 16epiE3-má redukálódik. Az E3 17-epimere szintén megtalálható a keringésben, ez a vegyület azonban a $16 \alpha \mathrm{OHEl}$ terméke.

A fázis I. átalakulásokat elsősorban a 17HSD enzimek katalizálják. Ezek az átalakulások kétirányúak. A 17ßHSDl az E1 E2-vé történő redukálását, míg a 17ßHSD2 az ellentétes irányú folyamatot katalizálja. Takeyama és mtsai a 17ßHSDl - és -2-típusú enzimlokalizációt vizsgálták humán placentaris mintákon immunhisztokémiai módszerrel, 31 esetben, 4-40 hetes terhességben. Az 17ßHSDl immunreaktivitását kizárólag a syncytiotrophoblastban észlelték a gestatio 4. hetétól kezdődően. A 17ßHSD2 enzimek immunreaktivitása először a terhesség 12 . hetében jelenik meg intervillosus ürt határoló endotheliumsejtekben. Az enzimet expreszszáló terület mérete a terhesség 13. hetétől szignifikánsan növekedett, és a 19. héten érte el a maximumot. A 17ßHSD2 megakadályozza az ösztrogének túlzott mértékû átjutását a magzati keringésbe az intravillaris magzati kapillárisok endothelialis sejtjeiben az E2-El inaktiválásának katalizálásával [17]. Későbbi tanulmányukban leírják, hogy a 17ßHSDl kizárólag a placentá-

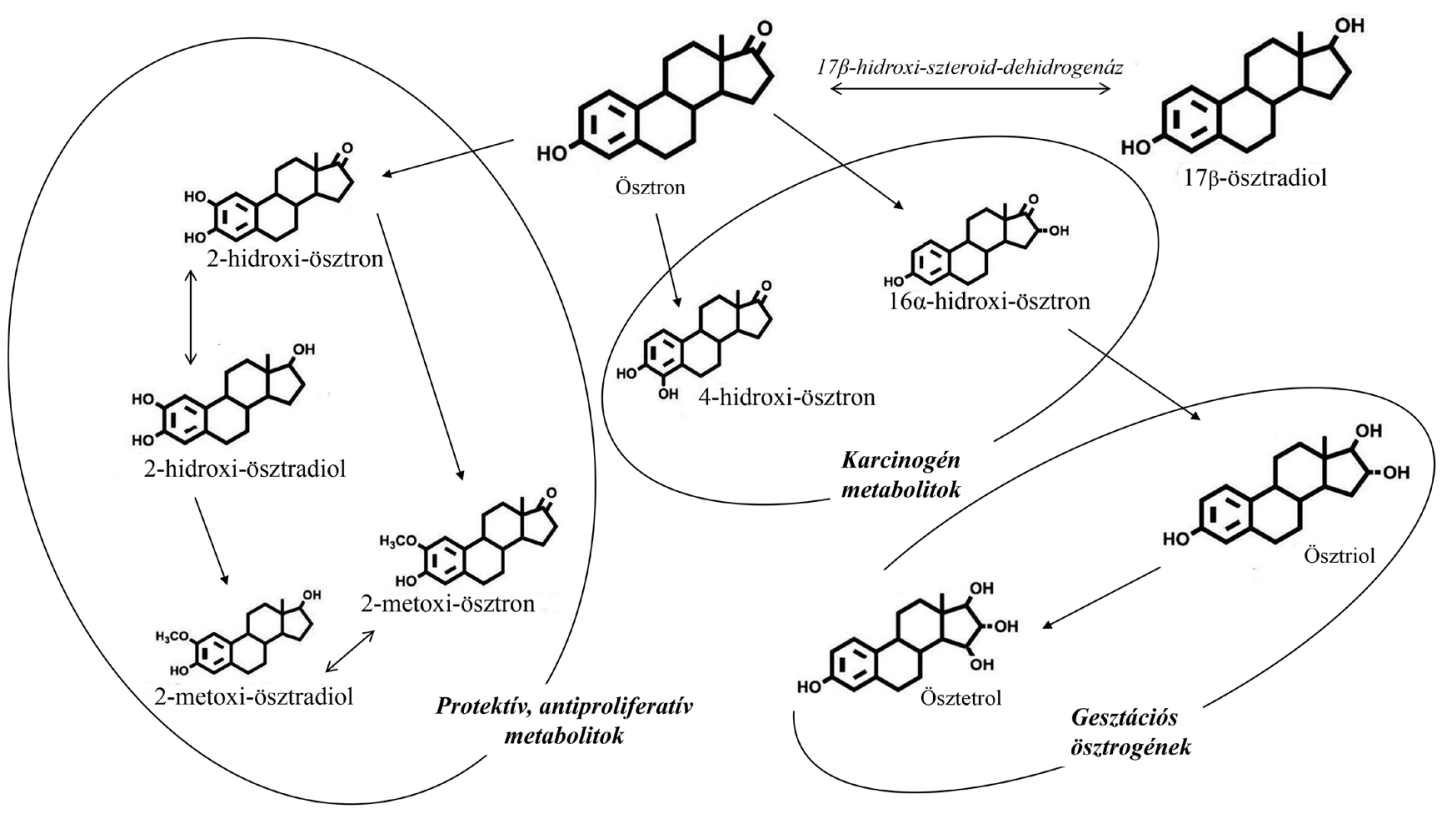

3. ábra $\quad$ Az ösztrogénmetabolitok élettani és kórélettani szerepe 
ban, míg a 17ßHSD2 számos anyai és magzati szövetben expresszálódik [18].

A II. fázisú reakciókat a SULT, UDP-UGT, NQOI, GST, STS és COMT mediálják, szulfát-, glükuronid- és metilezett glutationkonjugátumokat képezve $[12,19$, 20]. Egerekben vizsgálva az UGT különböző izoformáinak (UGTlal, - la6, - la9, -2a3, -2bl, -2b34 és -2b35) mRNS-expresszióját nem vemhes egerekhez hasonlítva 50\%-os emelkedést tapasztaltak, késői laktáció idején pedig az UGT-szintek visszatérnek a kontrollszintekre. A SULT izoenzimeit tekintve (lal, 2al/2 és 3al) az mRNS-expressziók 100-500\%-os növekedése tapasztalható a vemhesség és szoptatás során.

A katecholösztrogének irreverzibilis módon az El és az E2 C2 vagy C4 szénatomjának hidroxilezéséből származnak. A képződött ösztrogének (2OHE2, 4OHE2, 2OHEl és 4OHEl) hidroxilezett metabolitjai genomiális és nongenomikus hatású aktív molekulák. Ezeket a hidroxilációs folyamatokat különböző citokróm P450 izoformák közvetítik, amelyek többnyire a placentában és a magzati májban termelődnek. A placentában a 2-hidroxilációs lépés elsôsorban a CYPlAl- és a CYP3A4-aktivitásokon keresztül történik.

A placenta meglehetősen magas koncentrációban ösztrogén-2-hidroxilázt tartalmaz [21, 22], valamint COMT-ot termel [23-25], ami a 2MeOE2 megnövekedett képződéséhez vezet. Tehát a katecholösztrogének a placenta által termelt COMT enzim szubsztrátjaiként metoxi-ösztrogénekké alakulnak át (4. ábra). Terhesség során biológiailag az egyik legjelentősebb metoxi-ösztrogén a $2 \mathrm{MeOE} 2$, amelyet nem csupán a placenta állít elő, hanem az anya is termeli, mivel az anyai placentaris artéria endothelialis és decidualis sejtjei szintén képeznek COMT-ot [12].

\section{Az ösztrogénvegyületek konjugációja}

Az ösztrogének szulfatálódással és glükuronidálódással biológiailag inaktív vegyületekké konjugálódnak, vagy kinonszintáz által katalizált folyamatokban kinonokká, szemikinonokká alakulnak. Ezek a konjugált termékek az epével és a vizelettel választódnak ki. A szulfatált ösztrogénekké történő átalakulást a SULTs közvetíti. A reakció eredményeként vízben oldódó deaktivált termékek keletkeznek. A szulfatált ösztrogének nagy affinitással kötődnek az albuminhoz, így nem képesek kötődni az ösztrogénreceptorokhoz, ezáltal biológiailag inaktív hormonok képződnek. Az ösztrogének egyik legfontosabb szulfotranszferáz enzimje, a SULTIEl erős ösztrogénaffinitással rendelkezik. Az enzim jelen van számos anyai és magzati szövetben, köztük a májban, a mellékvesékben, az emlőben és a gastrointestinalis hámsejtekben is. A szulfatálódás reverzibilis folyamat, mivel a szulfatázok a szulfatált ösztrogéneket deszulfatált, aktív hormonokká is visszaalakíthatják [16].

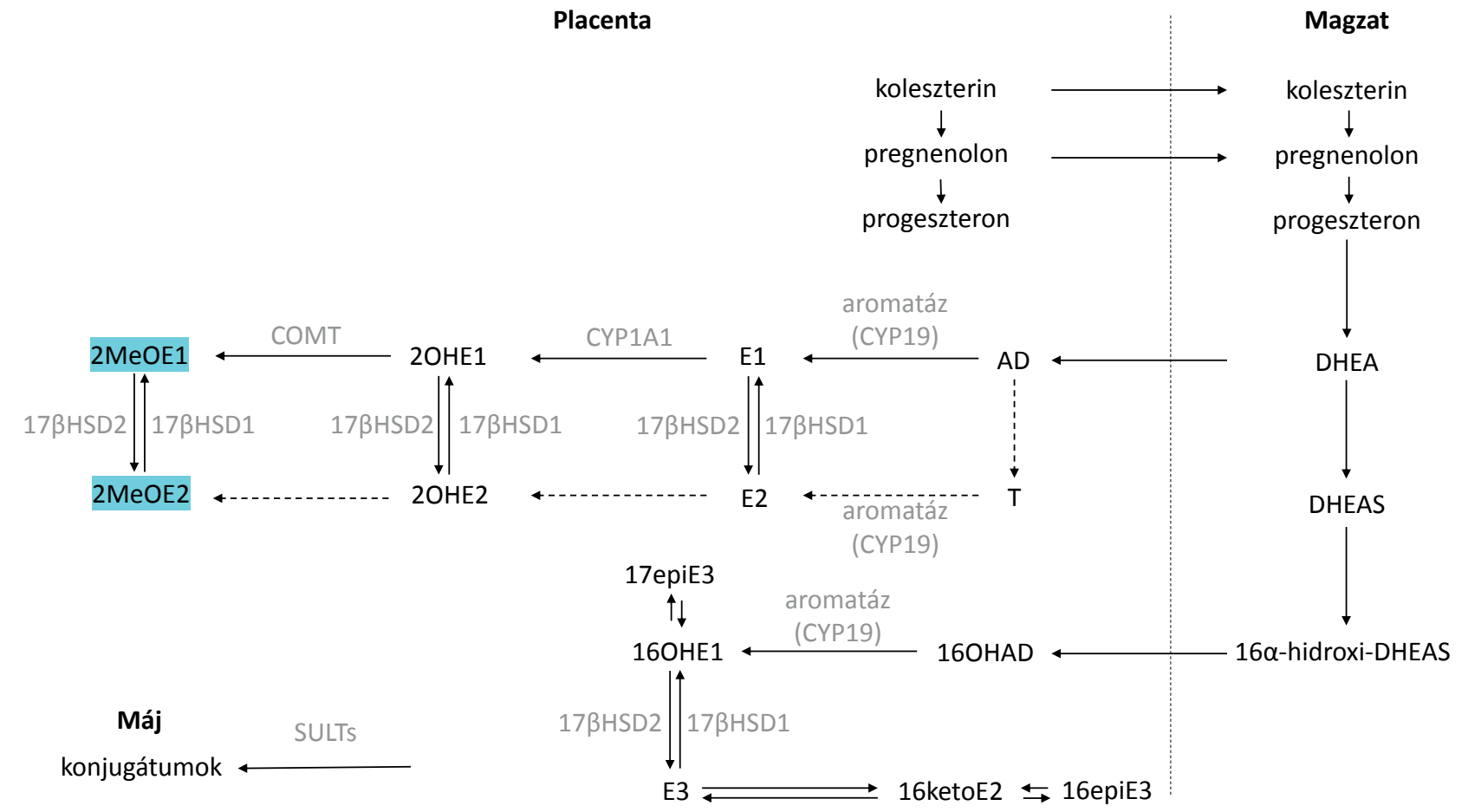

4. ábra

Ösztrogénmetabolizmus a terhesség során

$2 \mathrm{MeOE} 1$ = 2-metoxi-ösztron; $2 \mathrm{MeOE} 2$ = 2-metoxi-ösztradiol; $2 \mathrm{OHEl}=2$-hidroxi-ösztron; $2 \mathrm{OHE2}$ = 2-hidroxi-ösztradiol; $16 \alpha \mathrm{OHAD}=16$-alfahidroxi-androsztendion; $16 \alpha \mathrm{OHEl}=16$-alfa-hidroxi-ösztron; $17 \beta \mathrm{HSDl}=17$-béta-hidroxi-szteroid-dehidrogenáz-1; $\mathrm{AD}=(\mathrm{Catechol}$-O-methyltransferase) katechol-O-metiltranszferáz; COMT = (catechol-O-methyltransferase $)$ katechol-O-metiltranszferáz; DHEA = dehidroepiandroszteron; SULT $=$ szulfotranszferáz; $\mathrm{T}=$ tesztoszteron 


\section{Az ösztrogénmetabolom kapcsolata terhességi kórképekkel}

A gestatio alatt zajló ösztrogénmetabolom-változás megismerése perspektívát nyithat a különböző súlyosságú praeeclampsia, a gestatiós diabetes és az 1. trimeszteri fenyegető vetélés korai diagnózisához [26].

\section{Gestatiós magasvérnyomás-betegség (praeeclampsia)}

Egyes szerzők már korai vizsgálataik során a $2 \mathrm{MeOE} 2$ és a COMT szintjeit szignifikánsan alacsonyabbnak találták praeeclampsiában szenvedő nőknél [27, 28]. Mások egerekben találtak bizonyítékot arra vonatkozóan, hogy a COMT fontos a placenta és az embrió normális fejlődéséhez [29]. Ezenkívül 2MeOE2-szupplementáció protektív a várandósságra nézve, ami szintén arra utal, hogy a COMT fontos szerepet játszik a várandósság alatt a 2MeOE2 képződésével. Ugyanebben a vizsgálatban igazolták, hogy a COMT és a $2 \mathrm{MeOE} 2$ szerepet játszik a méh érrendszeri homeosztázisának, a vérnyomásnak, a vese glomerularis szerkezetének és a hypoxiás válasznak a szabályozásában is. Ezen élettani hatások mellett számos korábbi tanulmány még azt is kimutatta, hogy a $2 \mathrm{MeOE} 2$ erôs antiproliferatív hatással rendelkezik in vitro és in vivo $[22,30]$.

Más vizsgálatok hasonló eredményre jutottak. Pertegal és mtsai 53, praeeclampsiában szenvedó és 73 egészséges állapotos nő ösztrogénmetabolit-szintjeit hasonlították össze. A 2MeOE2-koncentrációt szignifikánsan magasabbnak találták a kontrollcsoportban, mint a PE-ben szenvedő betegeknél. A 2MeOE2-értékek negatív korrelációt mutattak ezenkívül a szisztoléscsúcs-artériás nyomással és a proteinuriával. Továbbá azoknál a nőknél, akiknél alacsonyabb 2MeOE2-koncentrációt mértek, a betegség komolyabb klinikai beavatkozást és komplexebb terápiát igényelt. Kimutatták azt is, hogy a 2MeOE2-szintek (mind a praeeclampsiában szenvedő betegek esetében, mind pedig a teljes populációban) szignifikáns korrelációt mutatnak a placentanövekedési faktor koncentrációival [31].

Seol és mtsai 15, gestatiós magas vérnyomással kezelt és 15 normotenziós kismama ösztrogénszintjeit hasonlították össze. Eredményeik szerint a 2MeOE2-szérumszintek szignifikánsan megemelkedtek azoknál a betegeknél, akiknél késői praeeclampsiát állapítottak meg. Ugyanakkor nem volt szignifikáns különbség a placentaCOMT-expresszióban a két csoport között. Következtetésük, hogy a késői megjelenésű PE során a $2 \mathrm{MeOE} 2$ fokozott szintje kompenzáló mechanizmusnak tekinthetö [32].

Jobe és mtsai $\mathrm{E} 1, \mathrm{E} 3$, valamint további hét ösztrogénmetabolit-vegyület vérplazmaszintjét hasonlították össze praeeclampsiás és egészséges kismamákban. A vizsgált vegyületek közül a 4MeOEl és a 16ketoE2 szintjét talál- ták szignifikánsan magasabbnak a betegségben, mint az egészséges nőkben [33].

A témában legutóbb, 2019 januárjában megjelent közlemény szerint praeeclampsiában a terhesség korai szakaszában az E2-koncentráció emelkedik, míg a gestatio második trimeszterére mindhárom ösztrogénanyagcsere- (2-, 4- és 16-os) útvonalon a metabolitok csökkenése figyelhető meg. Feltételezésük, hogy praeeclampsiában az ösztrogén-anyagcsere változása generalizáltan, nem enzimatikus okok miatt következik be [34].

\section{Gestatiós diabetes}

Az E2 szerepet játszik a teljes test, valamint a vázizomzat glikogénhomeosztázisának szabályozásában, ezáltal szerepe lehet a gestatiós diabetesben [35]. Qi és mtsai a terhesség előtti testtömegindex és a gestatiós diabetes kapcsolatát vizsgálták. Kimutatták, hogy a köldökzsinórvérből mért E2-szintek inverz módon korrelálnak a csecsemők születési súlyával. Ebből arra következtettek, hogy a köldökzsinórvérből mért alacsony E2-szint öszszefügg a terhességi cukorbetegséggel. Ezt támasztja alá, hogy az általuk vizsgált, gestatiós diabetesben szenvedő nők mindegyikénél alacsony volt az E2-szint [36]. Az E2 fokozza a $\beta$-sejt-proliferációt terhesekben, így a köldökzsinórvérből mért magas E2-szintek protektívek lehetnek az anyára nézve. Mások hasonló eredményre jutottak: szerintük az E2 jelenléte terhesség alatt nem növeli ugyan a $\beta$-sejt-proliferációt, de szerepe van a sejtek túlélésében a gyulladás indukálta apoptózis ellen. Továbbá, mivel az E2-produkció fó helye postmenopausában a zsírszövet, az E2 valószínúleg kapcsolatot jelenthet a zsírsejtek és a $\beta$-sejtek között, kismamákban is [37].

\section{Első trimeszteri fenyegető vetélés}

$X u$ és mtsai kapcsolatot kerestek az ösztrogének, progesztagének, glükokortikoidok, valamint metabolitjaik és a fenyegető vetélés kockázata között. Az alacsony tesztoszteron- és ösztrogénszintek jelezhetik előre az abortusz bekövetkeztét. Az ösztrogénnek és lebontási termékeinek (E1, E2, E3, 16 $\alpha \mathrm{OHE1}$, 4MeOE1, $2 \mathrm{OHE} 2$ és $4 \mathrm{MeOE} 2$ ) alacsony szintjét a prekurzorként múködő, de ekkor alacsony DHEA-koncentrációval hozták összefüggésbe, ezért azt feltételezték, hogy a vetélés az ösztrogénaktivitás csökkenésének tulajdonítható az első trimeszterben. Feltételezésüket 73 beteg vizsgálatával támasztották alá, akiknél DHEA-szupplementáció történt terhességük előtt. Megállapították, hogy a DHEAkezelés után a vetélés gyakorisága nemcsak csökkent, de elérte az átlagos fertilis populációkban megfigyelt arányt [38]. 


\section{Következtetés}

A kismamák szervezetében zajló ösztrogénszintézis, illetve a keletkezett vegyületek átalakulása rendkívül öszszetett folyamat, mely nem csupán egy szervre lokalizálódik, hanem részt vesz benne mind a magzati máj és mellékvese, mind a placenta. A terhességben megjelenő ösztrogének jelentős részben megegyeznek az azon kívül azonosított vegyületekkel, ugyanakkor a koncentrációkat és a mennyiségi arányokat tekintve alapvető különbségek vannak. Az ösztrogének sorsával kapcsolatban a gestatio alatt zajló folyamatok egyelöre nem tisztázottak, így a jövőt tekintve a terhesség az ösztrogénmetabolomikai kutatások fontos területét jelentheti. Várható egyúttal, hogy a vizsgált vegyületek körének bővítése további információval szolgálhat a gestatiós időszak különbözô betegségeinek pontosabb megismeréséhez.

Anyagi támogatás: A közlemény megírása anyagi támogatásban nem részesült.

Szerzői munkamegosztás: A szerzők egyenlő arányban és mértékben vettek részt az irodalomkutatásban és a közlemény megírásában. A cikk végleges változatát valamennyi szerző elolvasta és jóváhagyta.

Érdekeltségek: A szerzőknek nincsenek érdekeltségeik.

\section{Köszönetnyilvánítás}

A közlemény megírására a Nemzeti Bionika Program [1336/2017. (VI. 9.) Korm. határozat] keretében futó Biomarker projekt részeként került sor. A projekt forrását Magyarország Kormánya biztosítja a Nemzeti Kutatási, Fejlesztési és Innovációs Hivatalon keresztül.

\section{Irodalom}

[1] Seaman B. The greatest experiment ever performed on women: exploding the estrogen myth. Hyperion, New York, 2003.

[2] Pasqualini JR, Kincl FA. Hormones and the fetus. Chapter 2 Biosynthesis and metabolism of different hormones in the fetal and placental compartments. Pergamon Press, Oxford, 1985; pp. 73-172.

[3] Schwers J, Eriksson G, Diczfalusy E, et al. 15 $\alpha$-hydroxylation: a new pathway of estrogen metabolism in the human fetus and newborn. Biochim Biophys Acta 1965; 100: 313-316.

[4] Xu X, Keefer LK, Ziegler RG, et al. A liquid chromatographymass spectrometry method for the quantitative analysis of urinary endogenous estrogen metabolites. Nat Protoc. 2007; 2: $1350-1355$.

[5] Chatterton RT Jr, Geiger AS, Gann PH, et al. Formation of estrone and estradiol from estrone sulfate by normal breast parenchymal tissue. J Steroid Biochem Mol Biol. 2003; 86: 159-166.

[6] Falk RT, Brinton LA, Dorgan JF, et al. Relationship of serum estrogens and estrogen metabolites to postmenopausal breast cancer risk: a nested case-control study. Breast Cancer Res. 2013; 15: R34.

[7] Vásárhelyi B, Mészáros K, Karvaly G, et al. Focusing on tissue biomarkers. Estrogens as key players in the modulation of immune response and autoimmunity. [Fókuszban a szöveti biomarkerek. Az ösztrogének mint a szövetspecifikus immunválasz és autoimmunitás modulálásának kulcsszereplői.] Orv Hetil. 2015; 156: 2070-2076. [Hungarian]

[8] Ngo ST, Steyn FJ, McCombe PA. Gender differences in autoimmune disease. Front Neuroendocrinol. 2014; 35: 347-369.

[9] Tam A, Morrish D, Wadsworth S, et al. The role of female hormones on lung function in chronic lung diseases. BMC Womens Health $2011 ; 11: 24$.

[10] Michaud JE, Billups KL, Partin AW. Testosterone and prostate cancer: an evidence-based review of pathogenesis and oncologic risk. Ther Adv Urol. 2015; 7: 378-387.

[11] Moon JY, Choi MH, Kim J. Metabolic profiling of cholesterol and sex steroid hormones to monitor urological diseases. Endocr Relat Cancer 2016; 23: R455-R467.

[12] Berkane N, Liere P, Oudinet JP, et al. From pregnancy to preeclampsia: a key role for estrogens. Endocr Rev. 2017; 38: 123144.

[13] Milewich L, MacDonald PC, Carr BR. Estrogen 16 -hydroxylase activity in human fetal tissues. J Clin Endocrinol Metab. 1986; 63: 404-406

[14] Hickey M, Hart R, Keelan JA. The relationship between umbilical cord estrogens and perinatal characteristics. Cancer Epidemiol Biomarkers Prev. 2014; 23: 946-952.

[15] Tal R, Taylor HS, Burney RO, et al. Endocrinology of pregnancy. Endotext (Internet). Last update: December 7, 2015.

[16] Kaludjerovic J, Ward WE. The interplay between estrogen and fetal adrenal cortex. J Nutr Metab. 2012; 2012: 837901.

[17] Takeyama J, Sasano H, Suzuki T, et al. 17 $\beta$-hydroxysteroid dehydrogenase types 1 and 2 in human placenta: an immunohistochemical study with correlation to placental development. J Clin Endocrinol Metab. 1998; 83: 3710-3715.

[18] Takeyama J, Suzuki T, Hirasawa G, et al. 17ß-hydroxysteroid dehydrogenase type 1 and 2 expression in the human fetus. J Clin Endocrinol Metab. 2000; 85: 410-416.

[19] Chatuphonprasert W, Jarukamjorn K, Ellinger I. Physiology and pathophysiology of steroid biosynthesis, transport and metabolism in the human placenta. Front Pharmacol. 2018; 9: 1027.

[20] Thomas MP, Potter BV. The structural biology of oestrogen metabolism. J Steroid Biochem Mol Biol. 2013; 137: 27-49.

[21] Osawa Y, Higashiyama T, Shimizu Y, et al. Multiple functions of aromatase and the active site structure; aromatase is the placental estrogen 2-hydroxylase. J Steroid Biochem Mol Biol. 1993; 44: 469-480.

[22] Zhu BT. Catechol-O-methyltransferase (COMT)-mediated methylation metabolism of endogenous bioactive catechols and modulation by endobiotics and xenobiotics: importance in pathophysiology and pathogenesis. Curr Drug Metab. 2002; 3: 321-349.

[23] Boadi WY, Urbach J, Barnea ER, et al. Enzyme activities in the term human placenta: in vitro effect of cadmium. Pharmacol Toxicol. 1992; 71: 209-212.

[24] Zhu BT, Patel UK, Cai MX, et al. O-methylation of tea polyphenols catalyzed by human placental cytosolic catechol-O-methyltransferase. Drug Metab Dispos. 2000; 28: 1024-1030.

[25] Zhu BT, Wang P, Nagai M, et al. Inhibition of human catechol$\mathrm{O}$-methyltransferase (COMT)-mediated O-methylation of catechol estrogens by major polyphenolic components present in coffee. J Steroid Biochem Mol Biol. 2009; 113: 65-74.

[26] Smy L, Straseski JA. Measuring estrogens in women, men, and children: recent advances 2012-2017. Clin Biochem. 2018; 62: $11-23$.

[27] Rosing U, Carlström K. Serum levels of unconjugated and total oestrogens and dehydroepiandrosterone, progesterone and urinary oestriol excretion in pre-eclampsia. Gynecol Obstet Invest. 1984; 18: 199-205.

[28] Barnea ER, MacLusky NJ, DeCherney AH, et al. Catechol-Omethyl transferase activity in the human term placenta. Am J Perinatol. 1988; 5: 121-127. 
[29] Kanasaki K, Palmsten K, Sugimoto H, et al. Deficiency in catechol-O-methyltransferase and 2-methoxyoestradiol is associated with pre-eclampsia. Nature 2008; 453: 1117-1121.

[30] Zhu BT, Conney AH. Is 2-methoxyestradiol an endogenous estrogen metabolite that inhibits mammary carcinogenesis? Cancer Res. 1998; 58: 2269-2277.

[31] Pertegal M, Fenoy FJ, Bonacasa B, et al. 2-methoxyestradiol plasma levels are associated with clinical severity indices and biomarkers of preeclampsia. Reprod Sci. 2015; 22: 198-206.

[32] Seol HJ, Cho GJ, Oh MJ, et al. 2-methoxyoestradiol levels and placental catechol-O-methyltransferase expression in patients with late-onset preeclampsia. Arch Gynecol Obstet. 2013; 287: 881-886.

[33] Jobe SO, Tyler CT, Magness RR, et al. Aberrant synthesis, metabolism, and plasma accumulation of circulating estrogens and estrogen metabolites in preeclampsia implications for vascular dysfunction. Hypertension 2013; 61: 480-487.

[34] Cantonwine DE, McElrath TF, Trabert B, et al. Estrogen metabolism pathways in preeclampsia and normal pregnancy. Steroids 2019 ; 144: 8-14.
[35] Barros RP, Morani A, Moriscot A, et al. Insulin resistance of pregnancy involves estrogen-induced repression of muscle GLUT4. Mol Cell Endocrinol. 2008; 295: 24-31.

[36] Qi X, Gong B, Yu J, et al. Decreased cord blood estradiol levels in related to mothers with gestational diabetes. Medicine (Baltimore) 2017; 96: e6962.

[37] Nadal A, Alonso-Magdalena PA, Soriano S, et al. The role of oestrogens in the adaptation of islets to insulin resistance. J Physiol. 2009; 587: 5031-5037.

[38] Xu Q, Chen J, Wei Z, et al. Sex hormone metabolism and threatened abortion. Med Sci Monit. 2017; 23: 5041-5048.

(Kovács Krisztián, Budapest, Nagyvárad tér 4., 1089 e-mail: kovacs.krisztianl@med.semmelweis-univ.hu)

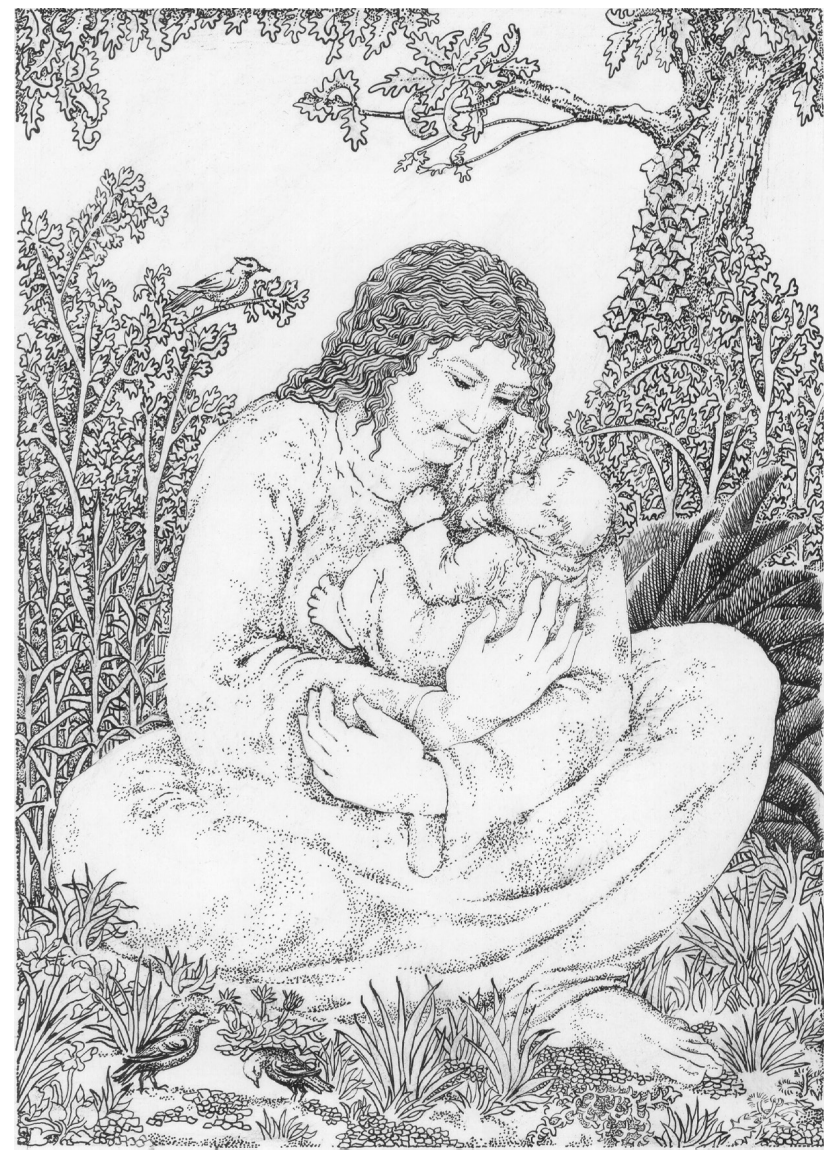

Révész Napsugár „Anyaság” grafikája

A cikk a Creative Commons Attribution 4.0 International License (https://creativecommons.org/licenses/by/4.0/) feltételei szerint publikált Open Access közlemény, melynek szellemében a cikk bármilyen médiumban szabadon felhasználható, megosztható és újraközölhető, feltéve, hogy az eredeti szerző és a közlés helye, illetve a CC License linkje és az esetlegesen végrehajtott módositások feltüntetésre kerülnek. (SID_1) 